\title{
Andrea Allen
}

\section{Curriculum Vitae}

\section{Andrea Allen}

Published on: Jul 15, 2020

DOI: https://doi.org/10.21428/1163c5ca.afea8379

License: Creative Commons Attribution 4.0 International License (CC-BY 4.0). 


\section{Contact Information}

andreanallen@clayton.edu

Clayton State University, Department of Social Sciences, 2000 Clayton State Boulevard, Morrow, GA 30260

\section{Web Presence}

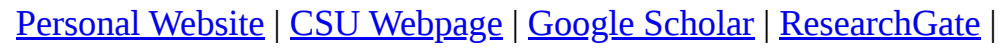

\section{Positions}

Associate Professor (August, 2018-present), Assistant Professor (August, 2013-July, 2018), Department of Social Sciences, Clayton State University

Vice Director, Criminology Open Ltd (May 2020-present)

Part-time Instructor (August, 2012 - May, 2013), Department of Criminal Justice and Criminology, Georgia State University

\section{Degrees}

PhD, Criminology and Criminal Justice, University of South Carolina, 2013

MS, Criminal Justice, University of Alabama, 2009

BS, (Magna Cum Laude), Justice Studies, Georgia Southern University, 2007

\section{Publications}

\section{Articles}

Allen, Andrea. 2021. Are campus police “real” police? Students’ perceptions of campus versus municipal police. The Police Journal, 94(2), 102-121. DOI: 10.1177/0032258X20906859.

Allen, Andrea and Scott Jacques. 2020. "He did that because I was Black”: Black college students perceive municipal police, not campus police, as discriminating. Deviant Behavior, 41, 29-40.

Hine, Kelly A., Louise E. Porter, Nina J. Westera, Geoffrey P. Alpert, and Andrea Allen. 2019. What were they thinking? Factors influencing police recruits' decisions about force. Policing \& Society: An International Journal of Research and Policy, 29(6), 673-691. 
Hine, Kelly A., Louise E. Porter, Nina J. Westera, Geoffrey P. Alpert, and Andrea Allen. 2018. Exploring police use of force decision-making processes and impairments using a naturalistic decisionmaking approach. Criminal Justice and Behavior, 45(11), 1782-1801.

Ruddell, Rick, Ryan Patten, Matthew O. Thomas, Andrea Allen, and Season Hoard. 2018. Emergency management on campus: Are we leaving the students behind? Campus Security Report, 15(7), 1, 4-5.

- Reprinted in: Ruddell, Rick, Ryan Patten, Matthew O. Thomas, Andrea Allen, and Season Hoard. 2018. Emergency management on campus: Are we leaving the students behind? Dean \& Provost, 20(3), 1, 4-5.

Allen, Andrea and Scott Jacques. 2018. Pairing fieldworkers with patrol officers: A study of supervising officers’ selections. Policing: A Journal of Policy and Practice, 12(2), 219-230.

Allen, Andrea. 2017. Do campus police ruin college students’ fun? Deviant Behavior, 38(3), 334-344.

Allen, Andrea. 2016. Stop and question campus policing. Policing: An International Journal of Police Strategies \& Management, 39(3), 507-520.

Rennison, Callie, Scott Jacques, and Andrea Allen. 2016. Victim injury and social distance: A national test of a general principle of conflict. Violence and Victims, 31(4), 726-751.

Allen, Andrea. 2016. Campus officers' sanctioning of alcohol-involved crime: Influences on discretionary decision making. Police Practice and Research: An International Journal, 17(3), 249-262.

Allen, Andrea. 2015. Campus police-citizen encounters: Influences on sanctioning outcomes. American Journal of Criminal Justice, 40(4), 722-736.

Jacques, Scott, and Andrea Allen. 2015. Drug market violence: Virtual anarchy, police pressure, predation, and retaliation. Criminal Justice Review, 40, 187-199.

Sevigny, Eric and Andrea Allen. 2015. Gun carrying among drug market participants: Evidence from incarcerated drug offenders. Journal of Quantitative Criminology, 31, 435-458.

Jacques, Scott, Richard Wright, and Andrea Allen. 2014. Drug dealers, retaliation, and deterrence. International Journal of Drug Policy, 25, 656-662.

Allen, Andrea. 2014. Campus officers' explanations of traffic stop sanctions. Police Quarterly, 17, 276301.

Allen, Andrea, and Scott Jacques. 2014. Police officers’ theories of crime. American Journal of Criminal Justice, 39, 206-227. 
Jacques, Scott, Andrea Allen, and Richard Wright. 2014. Drug dealers' rational choices on which customers to rip-off. International Journal of Drug Policy, 25, 251-256.

Jacques, Scott, and Andrea Allen. 2014. Bentham's sanction typology \& restrictive deterrence: A study of young, suburban, middle-class drug dealers. Journal of Drug Issues, 44, 212-230.

Allen, Andrea, and Scott Jacques. 2013. Alcohol-related crime among college students: A review of research and fruitful areas for future work. Criminal Justice Studies, 26, 478-494.

Allen, Andrea, and Celia C. Lo. 2012. Drugs, guns, and disadvantaged youths: Co-occurring behavior and the code of the street. Crime \& Delinquency, 58, 932-953.

Lo, Celia C., Young S. Kim, Thomas M. Allen, Andrea Allen, P. Allison Minugh, and Nicoletta Lomutto. 2011. Student delinquency: Grade level, protective factors, and school environment. Crime \& Delinquency, 57, 622-657.

\section{Chapters}

Allen, Andrea. 2015. Campus policing. In Roger G. Dunham and Geoffrey P. Alpert (Eds.), Critical issues in policing: Contemporary readings, $7^{\text {th }}$ edition. Long Grove, IL: Waveland Press, Inc.

Allen, Andrea, and Scott Jacques. 2013. Policing alcohol-related crime among college students. In Bonnie S. Fisher and John J. Sloan, III (Eds.), Campus crime: Legal, social, and policy perspectives, $3^{\text {rd }}$ edition. Springfield, IL: Charles C. Thomas Publisher.

\section{Other}

Jacques, Scott and Andrea Allen. 2018. "Criminology (GSU, Clayton)". Criminal Justice Grants Collections. 3. https://oer.galileo.usg.edu/criminal-collections/3

Davis, Jason, Andrea Allen, and Scott Jacques. 2017. "Introduction to Criminal Justice". Criminal Justice Grants Collections. 2. https://oer.galileo.usg.edu/criminal-collections/2

Allen, Andrea and Scott Jacques. 2017. "Criminal Justice Research Methods". Criminal Justice Grants Collections. 1. https://oer.galileo.usg.edu/criminal-collections/1

\section{Presentations}

Allen, Andrea. 2018. Free criminology and criminal justice courses: Ideas on transforming classes from traditional textbooks to no-cost materials. Paper presented at the Academy of Criminal Justice Sciences Annual Meeting, New Orleans, LA. 
Hoard, Season, Christina Sanders, Andrea Allen, Michael Gaffney, Ryan Pattern, Rick Ruddell, Stephen Sherman, and Matt Thomas. 2018. Police trust on college campuses: A national perspective. Paper presented at the Academy of Criminal Justice Sciences Annual Meeting, New Orleans, LA.

Sevigny, Eric L., Robert Kaminski, and Andrea Allen. 2016. Police use of force and suspect injury: The mediating role of drug and alcohol intoxication. Paper presented at the American Society of Criminology Annual Meeting, New Orleans, LA.

Allen, Andrea. 2016. College students' perceptions of campus and municipal police. Paper presented at the Academy of Criminal Justice Sciences Annual Meeting, Denver, CO.

Allen, Andrea. 2015. Theorizing convenience sampling in ethnographic research. Paper presented at the American Society of Criminology Annual Meeting, Washington, DC.

Allen, Andrea and Scott Jacques. 2014. Drug market conflict: Criminal, would-be criminal, and noncriminal victimization. Paper presented at the American Society of Criminology Annual Meeting, San Francisco, CA.

Allen, Andrea. 2014. Campus officers' explanations of traffic stop sanctions. Paper presented at the Western Society of Criminology Annual Meeting, Honolulu, HI.

Allen, Andrea. 2013. Police officers' perceptions of offense seriousness. Paper presented at the American Society of Criminology Annual Meeting, Atlanta, GA.

Allen, Andrea. 2012. Policing alcohol and related crimes on campus. Paper presented at the American Society of Criminology Annual Meeting, Chicago, IL.

Allen, Andrea. 2011. Theorizing the effect of police officers'status on assignment to a research project. Paper presented at the American Society of Criminology Annual Meeting, Washington, DC.

Allen, Andrea, and Eric L. Sevigny. 2010. The intersection of drug and gun markets: Evidence from an incarcerated population. Paper presented at the American Society of Criminology Annual Meeting, San Francisco, CA.

Allen, Andrea. 2009. Drug trafficking and gun carrying: A co-occurring phenomenon among AfricanAmerican male youth. Paper presented at the $12^{\text {th }}$ Annual Graduate Research Conference, University of Alabama, Tuscaloosa, AL.

Allen, Andrea, and Celia C. Lo. 2008. Drug trafficking and gun carrying: A co-occurring phenomenon of African-American male youth. Paper presented at the American Society of Criminology Annual Meeting, St. Louis, MO. 
Lo, Celia C., Thomas M. Allen, and Andrea N. Allen. 2008. Student delinquency: Grade level, protective factors, and school environment. Pro-seminar for Developmental Science Group, Human Development and Family Studies, University of Alabama, Tuscaloosa, AL.

\section{Grants}

“Criminology: No-Cost-to-Students Learning Materials for a Top Enrollment USG Course.” Textbook Transformation Grant, Affordable Learning Georgia (May, 2017 - December 2017). Project Leads: Scott Jacques and Andrea Allen $(\$ 10,800)$.

"Introduction to Criminal Justice: No-Cost-to-Students Learning Materials for a Top Enrollment USG Course.” Textbook Transformation Grant, Affordable Learning Georgia (January, 2016 - December 2017). Project Leads: Jason Davis, Andrea Allen, and Scott Jacques $(\$ 15,800)$.

“No-Cost-to-Students Learning Materials for Social Science Research Methods.” Textbook Transformation Grant, Affordable Learning Georgia (October, 2015 - May, 2017). Project Leads:

Andrea Allen and Scott Jacques $(\$ 10,800)$.

“Students' Perceptions of Police” (April 2015 - May 2016). Clayton State University, Undergraduate Research and Creative Activities Committee (URCAC). Principle Investigator: Andrea Allen $(\$ 2,250)$.

“Policing Crime on Campus” (October 2013 - July 2014). Clayton State University, Undergraduate Research and Creative Activities Committee (URCAC). Principle Investigator: Andrea Allen $(\$ 2,215)$.

\section{Courses Taught}

\section{@ Clayton State University}

Intro to Criminal Justice (seated and online)

Community Policing (online)

Corrections (online)

Crime in the US-Graduate Level

Criminal Investigations

Criminal Justice Internship (online)

Criminology (online)

Current Issues in Law Enforcement-Graduate Level (online) 
Internship for Political Science (online)

Juvenile Justice Seminar—Graduate Level (online)

Law Enforcement (seated and online)

Law Enforcement Administration

Law Enforcement \& Community (online)

Police, Courts, \& Corrections-Graduate Level (online)

Research Methods (seated and online)

Research Methods \& Applied Statistics-Graduate Level

Typologies of Crime

\section{@ Georgia State University}

Juvenile Offending

Research Methods

Social Science \& the American Crime Problem

\section{@ University of South Carolina}

Criminal Justice System

Corrections

Drugs and Crime

Policing

\section{Service}

\section{Editorial Positions}

Vice Editor, Journal of Qualitative Criminal Justice and Criminology (September, 2020-May, 2022)

\section{Manuscript Reviewer}

American Journal of Criminal Justice; Criminal Justice \& Behavior; Criminology, Criminal Justice, Law \& Society; Journal of Criminal Justice; Journal of Drug Issues; Justice Quarterly; International 
Criminal Justice Review; Police Practice and Research: An International Journal; Policing: An

International Journal of Police Strategies \& Management; Policing \& Society; Social Problems; Urban Affairs Review

\section{@ Clayton State University}

\section{Department}

Department of Social Sciences Online Coordinator, March 2020 - present

Department of Social Sciences Assessment Coordinator, August 2019 - present

Member of Department of Social Sciences Promotion \& Tenure Committee, August 2018—present

Member of the Department of Social Sciences Online Teaching and Standards Committee, April 2017 present

Undergraduate Program Coordinator, Criminal Justice, January 2017 - present

Member of the Department of Social Sciences Criminal Justice Search Committee, 2019

Chair of the Department of Social Sciences Political Science Search Committee, 2018

Member of the Department of Social Sciences Chair Search Committee, 2016

Chair of Department of Social Sciences Criminal Justice Search Committee, 2016

Chair of Department of Social Sciences Criminal Justice Search Committee, 2015

Member of Department of Social Sciences Political Science Search Committee, 2013

\section{College}

Member of the Dean’s Faculty Advisory Committee, 2014 - 2018

Member of the Mini Grant Committee, 2013 - 2016

\section{University}

Member of the Institutional Review Board (IRB), August 2018 - present

Member of Title IX Panelist Team, August 2018 - present

Member of the University Graduate Curriculum Committee, August 2016 - present

Member of Student Affairs, 2019 - 2021 
Member of the Student Behavioral Consultation Team (SBCT), 2017 - 2018

Member of the University Hearing Panel, 2017 - 2019

Member of the Campus Safety Task Force Committee, January 2016 - May 2018

Graduate Director, Master of Criminal Justice program, 2016 - 2019

Member of the University Graduate Affairs Committee, 2016 - 2019

Member of the University Undergraduate Curriculum Committee, 2015 - 2018

Member of Director of Public Safety Search Committee, 2018

Member of the Academic Affairs Working Group for the Implementation of HB 280 Campus Carry, 2017

Member of Public Safety Lieutenant Search Committee, 2015

\section{System}

Member of the University System of Georgia Advisory Committee for Criminal Justice, January 2017 present

\section{@ Georgia State University}

\section{College}

Judge for Andrew Young School of Policy Studies’ Public Service and Research End Event, 2013

\section{AWARDS, HONORS, AND MEMBERSHIPS}

\section{Clayton State University}

Creative Activities and Scholarship Enrichment (C.A.S.E.) Award, 2016-2017

Clayton State Student Athlete Outstanding and Favorite Faculty Honor, 2015

College of Arts and Sciences, Gene Hatfield Scholar of the Year Award, 2014-2015

Creative Activities and Scholarship Enrichment (C.A.S.E.) Award, 2014-2015

\section{University of Alabama, Masters Program in Criminal Justice}

Chair’s Merit Award for the Department of Criminal Justice, 2009

Alpha Phi Sigma, The National Criminal Justice Honor Society, President, 2008 - 2009 
Award for Higher Learning and Teaching for \$1,000, 2008

\section{Georgia Southern University, Undergraduate Program in Justice Studies}

Georgia Hope Scholar, 2003 - 2007

President's List, 4 semesters

Dean’s List, 2 semesters

\section{References}

Available on request 